\title{
1. Constitutions: between magic and deceit
}

\section{CONFLICTS AND PROJECTS}

A more absurd and sinister scenario can hardly be imagined: amid bloodshed and violence, the artillery pounding rebel-held areas, the police and secret services of the dictatorial regime arresting and killing protesters, bystanders and also children by the thousands, despotPresident Basher al-Assad, on 26 February 2012, called the Syrian people to a referendum on a new constitution. In the autumn of 2011, after the 'Arab Spring' had turned into civil uprising, then a war of the regime against the Syrian society, and finally hell, ${ }^{1}$ al-Assad had hand-picked a committee of framers to draw up a constitutional document to replace the constitution of 1973. Ironically, the old constitution had already been superseded by emergency law, which was lifted in April 2011 in an empty gesture to appease protest. Only two days after the referendum, al-Assad issued Decree No. 94 publishing the Constitution of the Syrian Arab Republic, which seemed to promise two significant changes: the text testified to divesting the ruling Ba'ath Party of its leadership role in society and state and limiting the president's term to two seven-year periods. ${ }^{2}$

1 International Crisis Group Working to Prevent Conflict Worldwide 'Popular Protest in North Africa and the Middle East (VII): The Syrian Regime's Slow-Motion Suicide' Middle East/North Africa Report No. 109 - 13 July 2011. For a more dramatic report 'from the inside of the revolution' see Samar Yazbek The Crossing: My Journey to the Shattered Heart of Syria (London: Ebury Press, 2016); Robin Yassin-Kassab Burning Country: Syrians in Revolution and War (London: Pluto Press, 2016).

2 'The leading party in the society and the state is the Socialist Arab Ba'ath Party.' Art. 8, 1973 Constitution of Syria. The revised section of Art. 8 now reads: 'The political system is based on the principle of political pluralism.' It takes a great deal of faith and denial to believe that these words mean what they say. 
Why would the Syrian despot bother about reconstituting his regime? Internally, an extra dose of legitimation seemed hardly necessary. Whatever the constitution might say, his supporters would loyally stay by his side in this bitter, uncivil war against oppositional movements and, more recently, the so-called 'Islamic State'. In contrast, the opposition movements that had boycotted the referendum would not trust the despotic regime no matter what and would perceive the situation in nonconstitutional terms as brutality. As was to be expected, the external observers, if they even took note of the constitutional move, labelled it a 'farce' and 'cynical ploy'. Hence, a new or revised constitution could only be addressed, as a demonstration of order and being-in-charge, to his coalition of partisans; other than that it could be expected to improve al-Assad's political reputation only if endowed with magic force. ${ }^{3}$ Maybe the despot knew that constitutions are not only invented to create union, commonality and order, but also and quite often serve as instruments of deceit. By 2017, the ruler and his allies had converted, with brute force, over a million Syrian citizens into refugees. Their constitution?

$$
* * *
$$

With a number of constitutional projects, ${ }^{4}$ the members of the former Estates-General and then National Assembly, revamped the Ancien Régime and set out to remake French society and polity. ${ }^{5}$ A constitution, echoing the perfect kingdom's equilibrium, ${ }^{6}$ certified the new normative order that transformed society into a 'nation'. The constitutional elites promised, first and foremost, to secure the rights of individuals and second the separation of powers. ${ }^{7}$ In reorganizing the country, the deputies 'codified a new language of politics and a new political imagery

3 By the same token, Turkish President Recep Tayyip Erdoğan staged a constitutional referendum in the aftermath of a mysteriously dilettante coup attempt and during the state of exception he had declared.

4 Cf. Marcel Gauchet La Révolution des Droits de l'Homme (Paris: Gallimard, 1989).

5 For a thorough analysis of the work of the National Assembly from 1789 until 1791: Michael P. Fitzsimmons The Remaking of France: The National Assembly and the Constitution of 1791 (Cambridge: Cambridge University Press, 1994).

6 'A kingdom ... where privileges upset all equilibrium ... is obviously a very imperfect kingdom.' Calonne to Louis XVI, 20 August 1786, quoted by Fitzsimmons The Remaking of France, 3.

7 'A society in which the observance of the law is not assured, nor the separation of powers not defined, has no constitution at all.' Art. 16 Declaration 
based on the new ideology of the nation' ${ }^{8}$ Their project crystallized into a political manifesto, completed on 26 August 1789, that took modern man (!) to task: the Déclaration des Droits de l'Homme et du Citoyen.

After two more years of intense debate and struggle, the political emotions disciplined by a sense of mission and accompanied by fear that the project might fail, the unifying ideal of the nation as well as concerns about negative reactions of foreign powers, ended the formative period of the French Revolution when on 3 September 1791 the National Assembly adopted the document and reconstituted the absolutist Ancien Régime as the first constitutional monarchy on French soil. This document, the members of the Assembly thought, would be the pillar of the new political framework. Reluctantly King Louis XVI appeared to accept the document, which redefined his status and role. Outside the royal chambers it was widely acclaimed as repudiating the tradition of domination and privilege - treating France like a 'colony with no past' as Madame de Staël later observed. ${ }^{9}$ Despite the acclaim, the edifice was doomed to collapse before long.

In the same month, Olympe de Gouges, speaking for all women who had been excluded from debating and drafting both the 1789 Déclaration and the 1791 Constitution, publicly disqualified both projects. She argued: '[T]he constitution is null if the majority of individuals comprising the nation have not cooperated in drafting it.' 10 She was doomed to die for these words on the guillotine, but ever since her declaration has haunted constitution-makers who camouflage in universal terms the exclusion of women, non-propertied classes, slaves, indigenous people and other groups of society.

In Olympe de Gouge's time, active citizenship was granted only to men who were French and residing in France, at least 25 years of age, paid direct taxes equal to three days' work, and could not be defined as

of the Rights of Man and of the Citizen, in: Frank M. Anderson ed The Constitutions and Other Select Documents Illustrative of the History of France 1789-1907 (New York: Russell \& Russell, 1908) 59-61.

8 Fitzsimmons The Remaking of France, 59.

9 Anne-Louise-Germaine Staël-Holstein Considérations sur les principaux événements de la Révolution française, vol. 1 (London: J.A. Latour, 1818) 368.

10 Olympe de Gouges 'Déclaration des Droits de la Femme et de la Citoyenne' in: Darline G. Levy ed (trans. Harriet Branson Applewhite and Mary Durham Johnson) Women in Revolutionary Paris 1789-1795 (Urbana: University of Illinois Press, 1980) 87-96. 
servants. ${ }^{11}$ The constitution survived for the time being. The exclusion of women was later corrected. However, the newly created normative order began to disintegrate when Louis XVI, too much trusted by the moderates, played his own game. Constitutional monarchy proved unworkable in times of war. On 10 August 1792, during the Paris insurrection, the National Assembly revoked the king's authority and charged him - quite adequately in those times - with refusing to defend the revolution and the constitutional regime. In September 1792 the National Convention declared France a republic.

Why had the National Assembly, from the very beginning, embarked upon and pursued this ambitious, time- and energy-consuming constitutional project? And why integrate into the scheme of government a king who could be suspected, especially after his failed escape attempt, to endanger the revolutionary project, instead of constituting a parliamentary or presidential democracy? The precarious plan, one may assume, was to couch the revolution in a moderate - in today's parlance: reformist - setting so as to protect it against extremism from within and counterrevolutionary movements from without. Constitutional realpolitik one might say.

In Russia, the Bolshevik cadres opted for a different constitutional strategy and followed a path of constitution-making distinguished by its revolutionary rhetoric and practices from the one pursued by their French forebears. Instead of projecting a reformist design for the exercise and legitimation of power, they limited the text and function of the 1918 Russian Constitution to describing the dictatorship of the proletariat, consisting of workers, soldiers and peasants, which had already been established during the October Revolution. The document, thus, incorporated changes already accomplished and in considerable part embodied in ordinary legislation. And the framers introduced two keywords - development and transition - and a general principle - socialist legality - for the understanding of rights, powers and constitutionalism in general within the overall socialist project:

Being guided by the interests of the working class as a whole, the Russian Socialist Federated Soviet Republic deprives all individuals and groups of

11 Jacques-Guillaume Thouret 'Report on the Basis of Political Eligibility, 29 September 1789' in: Lynn Hunt ed The French Revolution and Human Rights: A Brief Documentary History (Boston/New York: Bedford/St. Martin's, 1996) 82. 
rights which could be utilized by them to the detriment of the socialist revolution (1918 Russian Constitution, No. 23).

In 1924 the first Constitution of the USSR duplicated, after a delay of two years, the birth of the Soviet Union, uniting Russia, the Ukraine, White Russia and the Transcaucasian Republics of Armenia, Azerbaijan and Georgia. It only reiterated the official Manichaean narrative by setting up the (good) socialist camp of 'reciprocal confidence and peace, national liberty and equality, the pacific co-existence and fraternal collaboration of peoples' against the (evil) capitalistic camp marked by 'national hate and inequality, colonial slavery and chauvinism, national oppression and massacres, brutalities and imperialistic wars' (Part I).

According to the 'laws' of historical materialism, the Soviet Union had to be reconstituted whenever political and socio-economic development had reached a new stage, at least ideologically: in 1936 the Stalin Constitution expressed the new correlation of class forces and consolidated the principles of the new socialist state. In 1977 the Brezhnev Constitution documented, in constitutional rhetoric, a further step in the transition from socialism to communism. In its preamble it extolled the 'developed socialist society' and declared triumphantly that the aims of the dictatorship of the proletariat had been fulfilled and therefore, with a touch of magic, 'the Soviet state has become the state of the whole people' and not only of the workers and peasants.

One wonders why socialist states or rather cadres went down that path and adopted the rhetoric of liberal/political constitutionalism rather than relying on party programmes and four- or five-year plans or presenting, at least, a different vocabulary. As power maps, socialist constitutions remained inconsequential because no political status could be derived from a text that did not adequately describe the power of the people's representatives, the party and the party elites. As charters of rights (if they contained any) modelled after the liberal paradigm, they conveyed a different normative grammar in so far as rights were only granted relative to duties, placed in the shadow of the overriding interests of state and society and, in the absence of an institutional arrangement administering justice, could not be enforced anyhow. One also wonders why socialist constitutions, given their basically programmatic and symbolic nature, became obsolete rather than being revised, with the political and socioeconomic transition to the next historical stage. 'The constitution of a socialist state must change with the transition of society from one historical stage to another ... The constitution adopted in 1936 conformed to the period of the consolidation of socialism ... Naturally, the 
chief provisions of this constitution are now obsolete.' ${ }^{12}$ Naturally? Neither nature nor the nature of things or the semantic surface gives away the answer why socialist constitutional documents are not amenable to amendment and why socialist regimes tend to be (re)constituted in the first place. To revitalize their magic power of transformation?

$* * *$

In stark contrast to al-Assad's strategy of constitutional cynicism, confirmative authoritarian constitutionalism as it were, the South African experience of constitution-making leans to the side of hope and transformation. After the bitter and protracted struggle against the apartheid regime, against its daily atrocities and racism, the anti-apartheid coalition began a struggle over what the new society should look like and an anything but harmonious constitutional drafting process.

Assisted by supportive academic midwives from abroad, the new Constitution (1996) came into effect in February 1997, after passing two certification judgments handed down by the Constitutional Court. It had been debated, then drafted in a Multi-Party Negotiating Process (MPNP) and was finally promulgated by President Nelson Mandela in 1996, replacing the 1993 Interim Constitution. The preamble and the Founding Provisions echo the framers' aspirations that the constitution help overcome the injustices of the past, heal the divisions within society, and guide the country on its path to a society based on dignity, equality, non-racialism, non-sexism and a common citizenship.

The South African Constitution was meant to be different because it was committed - more strongly than other recent postcolonial constitutions $^{13}$ - to equality and social-legal transformation. The new legal

12 See Arieh L. Unger Constitutional Development in the U.S.S.R (London: Methuen, 1981) 174-175 quoting the programmatic statement made by Nikita S. Khrushchev, then First Secretary of the Communist Party of the Soviet Union.

13 The Constitution of the Independent State of Papua New Guinea (1975) contains several developmental clauses, e.g. 'In the development of the rules of the underlying law in accordance with ... adoption, etc., of certain laws ... particular attention shall be given to the development of a system of principles of natural justice and of administrative law specifically designed for Papua New Guinea, taking special account of the National Goals and Directive Principles and of the Basic Social Obligations, and also of typically Papua New Guinean procedures and forms of organization' (No. 60 - considered to be one of the 'Natural Principles of Justice'). 
culture was to be shaped by 'transformative constitutionalism'. ${ }^{14}$ The 'development clauses' most clearly express the message of the egalitarian project and what many thought would be the magical transformative power of the document: 'South Africa cannot make progress toward a society based on human dignity, equality and freedom with a legal system that rigs a transformative constitutional superstructure onto a common and customary law base inherited from the past and indelibly stained by apartheid.' ${ }^{15}$ Being different and transformative meant the new constitution did not strictly follow the liberal route towards limiting only government but was also understood to be applied horizontally and bind private persons, thereby regulating their conduct through the medium of a Bill of Rights.

Far from marking the end of history, the 1996 Constitution of South Africa and, as will be discussed below, the 2009 Constitution of the Plurinational State of Bolivia, one might argue, pursues a different project of modern constitutionalism - a project whose outlines had not been designed on 21 June 1776 by 'the good people of Virginia' assembled for the last time 'in full and free convention' to issue their Declaration of Rights and that was to shape many constitutions to come. Since then, societies all over the world - to be precise, in most cases their ruling elites - have just as solemnly proclaimed to pursue, on whatever political path, the agenda of self-government for a 'society of individuals' or of an authoritarian regime for its subjects, of uniting a population or plurality of states, to the effect that today there is hardly any country left without a document claiming to describe how the individuals there assembled were 'constituted' as a nation or people and their institutions as a state or federal union.

The somewhat different narrative - the constitutions of South Africa and Bolivia and a few other postcolonial constitutions tell their readers has a deliberately silenced and almost forgotten but recently remembered forerunner: the 1801 and 1805 Constitutions of Haiti. ${ }^{16}$ After the successful revolt against slavery and colonialism, the new elite not only declared

14 The concept was introduced by Karl Klare 'Legal Culture and Transformative Constitutionalism' 14 South African Journal of Human Rights (1998) 146. See also Dennis Davis and Karl Klare 'Transformative Constitutionalism and the Common and Customary Law' 26 Journal of Human Rights (2010) 403.

15 Davis and Klare 'Transformative Constitutionalism' at 403. See also Dikgang Moseneke 'Transformative Constitutionalism: Its Implications for the Law of Contract' 20 Stellenbosch Law Review (2009) 4.

16 Liberated from oblivion notably by Sibylle Fischer's insightful analyses of 'postrevolutionary constitutions', Sibylle Fischer Modernity Disawowed: Haiti 
'slavery ... forever abolished' but unmistakably and with a racial twist stated their commitment to an egalitarian society:

The Citizens of Hayti are brothers at home; equality in the eyes of the law is incontestably acknowledged, and there cannot exist any titles, advantages, or privileges, other than those necessarily resulting from the consideration and reward of services rendered to liberty and independence (Art. 3, 1805).

The law is the same to all, whether it punishes, or whether it protects (Art. 4, 1805).

At the threshold to what was to be referred to as 'modernity', Haiti's 'Black Jacobins' had gone far beyond the French revolutionaries' abolition of privilege when they introduced, under the umbrella of the modern narrative, the concept of a racialized citizenship: '[T]he 1805 Constitution contains what in today's lexicon would be called a set of radical postcolonial aspirations, a community imagined, through a legal narrative, as capable of doing something none of its models had done before: identifying both blackness and humanity as the basic signifiers of citizenship.' 17

The unitedstatesean constitutional regime coexisted comfortably with slavery until the Thirteenth Amendment was passed in 1865. And even thereafter the slaveholder logic was confirmed two years later by the infamous Dred Scott decision of the US Supreme Court ${ }^{18}$ as well as the decision in Plessy v. Ferguson ${ }^{19}$ of 1896, which declared racial segregation constitutional and inaugurated the doctrine of 'separate but equal'. In like spirit, the French Déclaration des Droits de l'Homme et du

and the Cultures of Slavery in the Age of Revolution (Durham NC: Duke University Press, 2004) 227 and 260. For a different perspective on the silencing of the Haitian revolution see Michel-Rolph Trouillot Silencing the Past: Power and the Production of History (Boston MA: Beacon Press, 1995).

17 Anne Gulick 'We Are Not the People: The 1805 Haitian Constitution's Challenge to Political Legibility in the Age of Revolution' 78 American Literature (2008) 802. See also: Doris L. Garraway "Légitime Défense": Universalism and Nationalism in the Discourse of the Haitian Revolution' in Doris L. Garraway ed The Tree of Liberty (Charlottesville VA: University of Virginia Press, 2008) 63, 80.

18 Dred Scott v. Sandford, 60 U.S. 393 (1857). The majority of the Taney Court held that 'a negro, whose ancestors were imported into [the US], and sold as slaves', whether enslaved or free, could not be an American citizen and therefore had no standing to sue in federal court, and that the federal government had no power to regulate slavery in 'the federal territories acquired after the creation of the United States'.

19 Plessy v. Ferguson, 163 U.S. 537 (1896). 
Citoyen, in all its philosophical splendour, did not prevent France from establishing colonial regimes, treating the colonized population as a lesser species than hommes, and trying to undo the liberation of slaves in Haiti. In stark contrast, Haiti dared to confront Anglo-American and in particular French constitutionalism with a rupture and consistency more radical than the 1776 and 1789 declarations of independence ${ }^{20}$ and the 1791 Bill of Rights by reversing the slave-master relation:

There cannot exist slaves on this territory, servitude is therein forever abolished. All men are born, live and die free and French (Art. 3, Toussaint Louverture Constitution of 1801).

No whiteman of whatever nation he may be, shall put his foot on this territory with the title of master or proprietor, neither shall he in future acquire any property therein (Art. 12, Dessaline's Constitution of 1805).

Rather than feigning colour blindness and ignorance of the reality of slavery and racism, 'the Haitian constitutions take the opposite direction and infuse distinctions of skin color with political meaning':21

All acception [sic] of colour among the children of one and the same family, of whom the chief magistrate is the father, being necessarily to cease, the Haytians shall hence forward be known only by the generic appellation of Blacks (Art. 14, Constitution of 1805).

It is true that the Haitian documents contain diverse accents and provisions that seem contradictory or reflect 'tensions and conflicting desires', ${ }^{22}$ such as, for example, the combination of liberty from slavery and the affirmation of French sovereignty ('All men are born, live and die free and French') or declaring the Haiti Constitution of 1801 'part of the French Empire, but ruled under particular laws', or the sacredness of property (1805). Yet, the Haitian post-revolutionary constitutions testify to an enlightened spirit and the courage to address the problems of social reality rather than sweeping them under the carpet. The results differ from liberal individualism and modernity but, by the same token, set forth a critique of 'white universalism' and defy it with both a 'black universalism' and the political-constitutional resignification of a racial category: 'Calling all Haitians, regardless of skin color, black is a gesture like calling all people, regardless of the sex, women: it both asserts

\footnotetext{
20 Fischer Modernity Disavowed, 201.

21 Ibid. at 227.

22 Ibid. at 228.
} 
egalitarian and universalist intuitions and puts them to a test by using the previously subordinated term of the opposition as the universal term.' ${ }^{23}$

Although Haiti fulfilled the promises of the Enlightenment and the 'modern project', as well as the French Revolution, by abolishing slavery and proclaiming racial equality, ${ }^{24}$ the mainstream of constitutional historiography and comparative constitutional law has so far silenced the constitutional revolution in Haiti, has failed to understand what it means and purports to write a constitution for an overwhelmingly illiterate society and to recognize former slaves as actors on the constitutional stage, very much like Federalists and Anti-Federalists or members of the Assemblée Nationale, generically 'black' Madisons and Lafayettes.

\section{NARRATIVES OF MAGIC AND DECEIT}

For over 200 years constitutional projects have oscillated between the poles of magic and deceit, depending on how ideology, myth and the symbolic dimension came into play. Constitutional magic appears in different guises. At the very place where the pre-modern polity commonwealth, state, nation or empire - was personalized and embodied by the monarch, from the end of the eighteenth century until the present day, the abstraction of the modern idea of government has manifested itself in a document as pure script. Almost by sleight of hand, a single written text - the declaration of rights or independence or the constitution - accompanied by ritual converted the population inhabiting a given territory into a political community referred to as 'people', 'nation', 'peuple', 'Staatsvolk', 'pueblo' and so on. These declaratory acts do something as they declare or constitute, they are performative: they communicate ideas, open up a new horizon of meaning and are scripts for events. So it is fair to say that it is not the people who create the declaration or constitution but the declaration or constitution that creates the people. ${ }^{25}$

23 Ibid. at 233.

24 Nick Nesbitt Universal Emancipation: The Haitian Revolution and Radical Enlightenment (Charlottesville VA: University of Virginia Press, 2008); Susan Buck-Morss Hegel, Haiti, and Universal History (Pittsburgh PA: University of Pittsburgh Press, 2009); Doris L. Garraway, "Légitime Défense"” 63.

25 See Jacques Derrida 'Declarations of Independence' in Negotiations: Interventions and Interviews, 1971-2001 (Stanford CA: Stanford University Press, 2002) 46-54. Jacques de Ville 'Sovereignty without Sovereignty: Derrida's Declarations of Independence' 19 Law and Critique (2008) 87. 
By the same token, constitutional witchcraft rendered invisible all power effective within the framework of government, depersonalized the power-holders into law. The personal bond of loyalty between ruler and ruled (subjects) was transformed into the impersonal, abstract obedience to law. After all that transformational magic had done its work, the result could be labelled, in more or less good faith, law-rule or, more graphically, as in the 1780 Constitution of Massachusetts, by the good men there assembled, a 'government of laws and not of men'. Similarly, Bills of Rights, customs, decisions and conventions function, somewhat counterfactually, as an unwritten constitution submitting, in the United Kingdom, New Zealand and Israel, the monarch or the popular sovereign to the disciplining grammar of representation, condensed in formulas such as King- or Queen-in-Parliament or, more commonly, constitutional monarchy or constitutional (parliamentary) democracy. Constitutions, it seems, are enshrouded by the aura of magic.

Magic may very well be nothing but the bright side of deceit - for instance the mantra that constitutions are colour blind;26 the Syrian despot trying to convert his war against the people into a constitutional moment; Soviet cadres setting themselves up as executors of the laws of history; a propertied elite translating their particular economic interests into a catalogue of universal rights; or the 1943 Constitution of the Philippines, effective during the Japanese occupation, imploring the aid of Divine Providence and '... [the people] hereby proclaim[ing] their independence'. ${ }^{27}$ With more exuberance a Chinese observer of the Japanese-Russian War attributed Japan's victory to its constitution. The power of a constitution, a historian wrote, 'equals the power of a million soldiers' ${ }^{28}$

All of the above intimates that comparative constitutional studies have to combine realism with critical spirit, like the Haitian framers who were very aware of their slaveholding neighbours, and look at the dark side of

26 Courageously deconstructed by half a sentence of Art. 14, Constitution of Haiti (1805): ' ... the Haytians shall hence forward be known only by the generic appellation of Blacks'.

27 Securing 'the blessings of independence and democracy under the rule of law and a regime of truth, justice, freedom, love, equality, and peace' (preamble, Constitution of the Republic of the Philippines 1987), while still an exacting task, seems more realistic.

28 Jingxiong Wu Studien zur Rechtsphilosophie (Beijing: Qinghua University Press, 2005) 143; and Sufan Pan ed Die Verfassungsgeschichte der Republik China (1935) 3 - quoted by Xiaodan Zhang Stufenordnung und Verfahren der Setzung von Rechtsnormen in der Volksrepublik China (Frankfurt 2017 unpublished manuscript on file with the author). 
self-congratulatory reports handed down by framers and reproduced by normativist theories. What appears like an enchanted forest may be a thicket of ideology. So disenchantment is one of the important tasks of comparative constitutional studies. A disenchanted hermeneutics might help, for example, to decipher the final signatory paragraph of Haiti's 1805 Constitution not as wishful thinking or pure rhetoric but addressing the dangers of the antislavery project:

We commend it [the constitution] to our descendants and, in homage to the friends of liberty and the philanthropists in all countries, as a sign of divine goodness, which, as a result of his immortal decrees, has provided us with an occasion to break our irons and to constitute ourselves as free, civilized and independent people.

Constitutional realism and disenchantment, while taking the documents seriously, are easier proclaimed than done. 'There is no outside-text.' 29 Quite so. How then to study and compare constitutions? For the sake of manageability, I attempt to pursue three lines of research, methodological and theoretical:

First, assuming that every constitution has something interesting to tell, I shall look at as many constitutions as possible, notably at otherconstitutions, without pretending to render a comprehensive account or offering a representative selection. Whatever its defects and deficiencies, I find this approach preferable to both selection of the happy and hegemonic few constitutions and a Sisyphus study of all constitutions of the world.

Second, whether this qualifies as deconstructive or not, I also focus on what appear to be marginal documents and accidental features, hardly ever noted in the discourse. I hope they can be plausibly read as both confirming and subverting the story of constitutional magic and deceit.

Third, the no-outside-text, vulgarized as context, covers a wide terrain. Taking the texts seriously also means that there is hardly sufficient time and space for analysing what is conventionally referred to as context political constellations, the economy, social conflicts, the culture of constitutionalism, etc. Writing a 'layered narrative' 30 may indicate one possible path I suggest comparative constitutional studies might take, not more.

29 Jacques Derrida Of Grammatology (G. Spivak trans., Baltimore MD: Johns Hopkins University Press, 1976) 158f.

30 Günter Frankenberg 'Comparing Constitutions: Ideas, Ideals and Ideology

- Toward a Layered Narrative' 4 International Journal of Constitutional Law (2006) 439. 
And fourth, there is always the danger that by concentrating on constitutional documents one gets entrapped by the magic charm of constitutionalism and does not see the mystification of power and deceit. Comparative constitutional studies cannot be had without risks.

\section{CONSTITUTIONAL RHETORIC}

The turn from the eighteenth to the nineteenth century is generally regarded as the time when enlightened framers set up and filled the cradle of modern constitutionalism - a set of ideas, ideals, institutions and ideologies which are meant to domesticate the establishment of political power and mediate its exercise by providing a description and normative concept of polities as well as setting up a scaffold of legality.

Since those revolutionary days, the term 'constitution' has belonged to the prominent signs and ideological icons of modernity. ${ }^{31}$ Nations, treaties, democracies, rule-of-law regimes and catalogues of human rights were given or claimed to have a constitutional pedigree. Since then, scholars have systematically, in enlightenment's cone of light, pondered on good constitutional theory and practice. They have tried to meet the demand for constitutions, have filled libraries - recently also cyberspace - with treatises and articles explaining how to make and apply them. Since 1776, 1787, 1789 and 1805 constitutional documents - whatever their design, form, content, text and subtext, and whatever their context have proliferated (not Haiti's 1805 Constitiution though) as a widely imitated and varied pattern of ordering conflicts, a matrix for argument and institutional arrangements, and a source of symbolic images.

Originally constitutional documents were tailored to the territorial boundaries of nation states, later also regions, and the social structure of bourgeois societies, liberated from feudalism and later slavery. In the course of time, they came to inhabit also supra- and transnational spaces and were fitted into a diversity of socio-political structures - class antagonism, apartheid, postcolonial renewal, dictatorship and so on. They distinguished polities as constitutional monarchies, states, republics, federal systems or supranational bodies, democracies or dictatorships of the proletariat by serving as carriers for varied schemes of political participation and rule, underscored by catalogues of fundamental rights and shared values.

31 Alain Touraine Critique de la Modernité (Paris: Fayard, 1992). 
Constitutions have created - and are burdened with - many expectations: that struggles can be won by converting them into constitutional controversies; that interests will have more legitimacy and force if only reformulated in the language of fundamental rights; that governors can be brought under control within constitutional schemes of separation and balance of powers, as well as bureaucratic discretion constrained by constitutional principles, like proportionality. Some of these expectations have been met, others considerably disappointed.

Constitutionalism introduced a new vocabulary for, mindset and mode of establishing, legitimizing and limiting political authority as well as founding of a polity. Pre-modern leges fundamentales designated a political order sanctioned by divine will or holy tradition; today the Basic Law of Saudi Arabia (1992) ${ }^{32}$ and the 2008 Constitution of Bhutan, a democratic constitutional monarchy, still conform to that, one might think, somewhat outdated convention. Modern, that is, non-traditional constitutions usually refer to a secular 'Frame of Government' (Constitution of Pennsylvania 1776), 'règlement fondamentale, qui détermine la manière dont l'autorité publique doit être exercée' (Emer de Vattel), 'Organization of the State' (Stalin's 1936 Soviet Constitution) or supranational treaty (European Union). They convert mythical narratives of a founding moment into normative orders:

We the People, in Order to form a more perfect Union ... do ordain and establish this Constitution (1787 USA).

WE, THE PEOPLE OF INDIA, having solemnly resolved ... do HEREBY ADOPT, ENACT, AND GIVE OURSELVES THIS CONSTITUTION (1949 India).

After the founding of the People's Republic, the transition of Chinese society from a new-democratic to a socialist society was effected step by step (1982 China).

We, the Bolivian people, of plural composition, from the depths of history, inspired by the struggles of the past ... construct a new State in memory of our martyrs (2009 Constitution of Bolivia).

Constitutions are fraught with ideas, ideals and ideology. ${ }^{33}$ So they hardly render an accurate description of social reality, nor can they be read as

32 'The Kingdom of Saudi Arabia is a sovereign Arab Islamic state with Islam as its religion; God's Book and the Sunnah of His Prophet, God's prayers and peace be upon him, are its constitution, Arabic is its language and Riyadh is its capital.' Art. 1, Basic Law of Saudi Arabia.

33 See Frankenberg 'Comparing Constitutions', 439. 
manuals instructing their readers about the actual working of the institutional arrangement they lay out. At best, they indicate how societies rather their constitutional elites - envision coping with or camouflaging the business of establishing and exercising authority and bringing about social cohesion. If written in good faith, they can be commanding or at least aspirational texts, however definitely not blueprints:

[To constitute a] State based on respect and equality for all, on principles of sovereignty, dignity, interdependence, solidarity, harmony, and equity in the distribution and redistribution of the social wealth, where the search for a good life predominates ... (Constitution of Bolivia).

[T]o constitute India into a SOVEREIGN SOCIALIST SECULAR DEMOCRATIC REPUBLIC and to secure to all its citizens: JUSTICE, social, economic, and political; LIBERTY of thought, expression, belief, faith and worship; EQUALITY of status and opportunity; FRATERNITY assuring the dignity of the individual and the unity and integrity of the Nation ... (Constitution of India).

The basic task of the nation in the years to come is to concentrate its efforts on socialist modernization. Under the leadership of the Communist Party of China and the guidance of Marxism-Leninism and Mao Zedong Thought, the Chinese people of all nationalities will ... follow the socialist road (1982 Constitution of China).

Many polities have followed one or the other the path - to 'a more perfect Union' (1787 Constitution of the United States), a 'free state sovereign and independent of any other power in the universe a national union' (1805 Constitution of Haiti), nation (1853 Constitution of Argentina) or 'ever closer union among the peoples of Europe' (1992 Treaty on European Union). Others proclaim to seek entry into 'the human family' (1997 Constitution of Burkina Faso; 1992 Constitution of the Czech Republic). Yet others pledge to foster world peace and international solidarity, promise 'never again [to] be visited with the horrors of war through the actions of government' (1947 Constitution of Japan) or realize 'our high responsibility before the present and future generations' (1995 Constitution of Kazakhstan). Most settle with less haughty but maybe more pressing goals, such as 'a free and independent judiciary' (1990 Constitution of Namibia), building 'a country belonging to all multi-ethnic people' (1991 Laos) or advocating 'Papua New Guinean forms of participation, consultation, and consensus, and a continuous renewal of the responsiveness of these institutions to the needs and attitudes of the People' (1975 Constitution of Papua New Guinea). All in all, hyperbole has not done constitutional projects much good - outside the circle of professional constitutionalists. 
Whatever vision or interest, anxiety or historical experience may have left its imprint on the text, constitutional documents almost invariably become symbols of a people's identity and aspirations because they offer a language one can use for one's engagement in struggle. They come to life in controversy when individuals, movements, social groups or parties translate their expectations and hopes into constitutional arguments rights come first, lessons about 'wide margins of appreciation' will follow later. In due course, they learn about gaps and indeterminacy. Anyone involved in constitutional disputes learns that constitutions, like any other legal text, have to be read, decoded and converted into plausible arguments, which have to be defended against other plausible arguments. And they also learn that one should avoid committing the 'formalist error' ${ }^{34}$ which occurs when readers of constitutions believe a specific provision entails a specific result or conclusion - 'one right answer' 35 - when, in fact, participants in the constitutional conversation can generate lege artis other likely results or conclusions that are also equally compatible with the same provision.

Comparative constitutional studies have to deal with texts and practices - practices shaped by projects, arguments and conflicts. In comparison, texts may come to life - or remain silent if read with haste. It is not at all easy to identify the traces of conflicts and the imprints of the particular contexts in constitutions because these imprints and traces are often hidden underneath a rhetoric that suggests universality or denies the particular suffering. However, comparative constitutional studies, to make a difference, should look at the margins, decipher the rhetoric and start conversation between centres and peripheries.

34 Duncan Kennedy 'Legal Formalism' in: Neil Smelser and Paul Baltes eds Encyclopedia of the Social Sciences 13 (Amsterdam: Elsevier, 2001) 8634-8635.

35 The 'one right answer' thesis was developed by Ronald Dworkin: A Matter of Principle (Cambridge MA: Harvard University Press, 1985). 